\title{
Theofilos
}

A Nordic open access journal in Theology, Philosophy and Culture

Published by NLA University College - in partnership with Johannelund School of Theology

Available at www.theofilos.no

\section{Kirken og velferdsstaten 1}

\author{
Aud V. Tønnesen \\ Dekan og professor ved Det teologiske fakultet, Universitetet i Oslo \\ a.v.tonnessen@teologi.uio.no
}

\begin{abstract}
I Norge ble etterkrigstidens politiske ambisjoner om en omfattende velferdsstat møtt med kritikk fra deler av den kirkelige elite. Denne kritikken er igjen aktuell i forbindelse med en nylig fremlagt doktoravhandling. ${ }^{2}$
\end{abstract}

Nick Spencer, som er tidligere forskningsdirektør for tenketanken Theos i England og nå forsker, utfordrer med sin doktoravhandling Multi-dimensional personhood and the welfare state 3 til teologisk nytenkning om velferdsstaten og forholdet mellom kirke og velferdsstat. Det er både relevant og riktig. Det er imidlertid samtidig viktig å understreke at en referanse til velferdsstaten ikke er noen generell referanse til like former for stater. Det er relativt store variasjoner mellom velferdsstater i Europa, noe som er knyttet til nasjonalstatenes historiske utforming og til den politiske utvikling i respektive land.

Med velferdsstat menes som regel den moderne statsutvikling i vest-europeiske land etter andre verdenskrig, selv om begrepet har vært i bruk lengre. I mellomkrigsårene og krigsårene fant det sted en stor utveksling av tanker og ideer om hvordan den moderne staten skulle utformes, for å bygge opp under mål om fred og stabilitet. Det ble veldig tydelig under 2. verdenskrig med Atlanterhavserklæringen (1941) og den britiske Beveridgeplanen (1942), for eksempel. Krigen ble forstått som en følge av økonomisk krise og sosial uro. Fred var derfor ikke bare forstått som fravær av krig, men fred skulle også bygges gjennom politiske tiltak som ga sosial og politisk stabilitet. Det var en nokså allmenn oppfatning i vestlige politiske kretser at de totalitære ideologier og politiske systemer var muliggjort av en politikk som ikke hadde klart å skape sosial trygghet. Derfor skulle det, når krigen tok slutt, skje en gjenreisning der staten tok en mer aktiv rolle for å sikre at innbyggerne hadde grunnleggende sosial trygghet $\mathrm{i}$ form av bolig, økonomisk understøttelse ved bortfall av inntekter grunnet sykdom eller arbeidsledighet, allmenn tilgang til helsetjenester, skole osv.

Beveridgeplanen la vekt på at det måtte være et minimum av økonomisk basis for alle og at de sosiale velferdsytelsene måtte være universelle. Dette inspirerte norske politikere og fagbevegelse og var en medvirkende bakgrunn til de nye velferdsstatlige mål som ble satt for Norge etter krigen. Nå var det ulike syn rundt omkring i vestlige land når det gjaldt hvordan minimumsytelser skulle forstås, hvilket nivå de skulle ligge på og hvor omfattende det universelle skulle være. Her gikk Norge for en mer omfattende ordning enn England, for eksempel. Felles var at statens rolle som aktør på helse- og sosialfeltet økte, men også her var det forskjeller. De skandinaviske land, med sin historiske tette og forholdsvis harmoniske integrering av kirke og stat, ga kanskje særlige forutsetninger for en sentralisert velferdsstatsutbygging, der staten var, som historiker og teologiprofessor Berge Furre har sagt, den gode makt, som skulle sørge for alle. I 
(Vest-)Tyskland ble for eksempel velferdsstatsutviklingen annerledes, fordi man etablerte en føderativ statsmakt, og fordi man la seg på en ordning der stat, fagbevegelse og religiøse/frivillige organisasjoner samarbeidet.

I Norge ble etterkrigstidens politiske ambisjoner om en omfattende velferdsstat møtt med betenkning og kritikk fra deler av den kirkelige elite, om man kan bruke et slikt uttrykk. Enkelte biskoper (fremfor alt Eivind Berggrav i Oslo) og flere prester fryktet at velferdsstaten i Arbeiderpartiets støpning skulle bli en totalitær sekulær stat som fortrengte kirken fra sivilsamfunnet og gjorde den overflødig. Historisk hadde kirken og kristelige organisasjoner spilt en viktig rolle særlig innenfor det som var kalt den offentlige fattigpleien. Prester og biskoper hadde hatt en rolle innenfor det offentlige systemet gjennom fattigkommisjoner (slik de også hadde det innenfor skolevesenet), og i andre halvdel av 1800-tallet hadde en rekke filantropiske initiativ ført til organisert frivillig kristelig arbeid for å lindre fattigdommens lidelser og sykdom. Dette arbeidet fryktet man ville bli fortrengt og erstattet av statlig og kommunalt arbeid.

Når jeg leser intervjuet med Spencer, ${ }^{4}$ så tenker jeg at han beskriver et forhold mellom kirke og stat som særlig reflekterer forholdene i en del katolske land og i anglosaksiske områder, men kanskje mindre de protestantiske nordiske. Reformasjonen endret mye, og i DanmarkNorge ble omsorgen for syke og fattige reorganisert. Den danske statsviteren Tim Knudsen har uttalt at jo lengre sør i Europa man kommer, jo vanskeligere har det vært for staten å kontrollere det sosiale feltet. Det knytter han til den katolske kirkes makt og innflytelse på det området. I de nordiske protestantiske landene er det annerledes, fordi med reformasjo- nen overtok kongen det overordnede ansvar for å hjelpe fattige og syke, samtidig som det i praksis ble overdradd myndighet for dette til biskoper og prester, noe som skapte en integrasjon av det kirkelige i det statlige. Ordningene som ble bygd opp baserte seg på kongelige forordninger.

Spencers perspektiv blir derfor noe snevert og unyansert som et universelt uttrykk for europeisk statsutvikling, når han beskriver 1900 års historie som en historie nesten uten endringer hva gjelder kirkens rolle på det sosiale området og utdanningsfeltet. Hans analyse mangler rett og slett et konfesjonelt filter. Når det er sagt, mener jeg han får godt frem hvordan kirkens rolle endres og dens offentlige betydning reduseres etter andre verdenskrig, og at det også gjelder Norge. Det begynner tidligere, men det skjer grunnleggende forandringer som kan knyttes til fremveksten av velferdsstaten. Det var også grunnen til at en del norske teologer advarte mot velferdsstatsutbyggingen. Biskop Berggrav var mindre optimistisk enn Canterburys erkebiskop William Temple og fryktet at velferdsstaten forrykket balansen som toregimentslæren forordnet. Faren var ikke at kirken strebet etter politisk makt, men at staten vokste til å bli det eneste borgerne trengte. I et berømt foredrag, holdt i 1952 i Hannover under Det Lutherske Verdensforbundets andre generalforsamling, advarte han mot en velferdsstat som erstattet Gud med seg selv og ble en omnipotent «AllFader». Berggrav fryktet at det diakonale arbeidet ville svekkes og bli borte. Det var både en teologisk og politisk analyse. Det er imidlertid verdt å merke seg at i en del diakonale miljøer var man mer positive til planene om en velferdsstats, fordi man opplevde at nøden var stor og at større grep var nødvendige. Diakonale organi- 
sasjoner kunne ikke løse utfordringene alene.

Velferdsstaten som et prosjekt er et typisk etterkrigsfenomen i Europa. På 1950-tallet fins det eksempler på teologisk refleksjon rundt forholdet kirke og velferdsstat flere steder. Berggrav er den mest profilerte i norsk sammenheng, og han var pessimistisk. Han fryktet ikke bare at staten ville bli en "All-Fader» (et teologisk uttrykk som jo kan ses i sammenheng med politiske metaforer som «landsfader»), men også at det ville endre menneske og samfunnet, at menneskene ville bli mer kravstore og slutte å bry seg om hverandre, og at samfunnet ville bli kaldt. Rettigheter garantert av staten kunne svekke båndene og tiltakslysten hos folk. Under her lå en gammel spenning der rettigheter og barmhjertighet ble stilt opp mot hverandre, og hvor kirken og kristelige organisasjoner ofte hadde talt mot at sosial understøttelse skulle være basert på rettigheter. Det ville, mente man, skape et samfunn uten sammenheng. Barmhjertighet og frivillighet var sosialt lim. Tanken var at dersom man hjalp noen som svar på et krav og en rett, ble man likegyldige overfor hverandre. Hjelpen skulle være frivillig og gis ut fra kjærlighet, slik at det kunne skape endringer i sinn både hos giver og mottaker (det skulle være godt å gi, og man skulle være takknemlig for å få). Nå er det neppe mange som ønsker seg tilbake til en tid der hjelp til å dekke grunnleggende behov var noe man kunne være heldig å få. Imidlertid ligger det i Berggravs kritikk også et annet og kanskje mer interessant poeng, nemlig at samfunn og fellesskap ikke bare kan bygges ovenfra, det må også bygges nedenfra.

Det har vært stor utvikling innenfor velferdsstatene, og situasjonen i England og Norge er til dels veldig forskjellig. I
Norge har det offentlige et større sosialt ansvar, og ytelsene som gis er mye rausere enn hva tilfellet er i England. Men det har de siste tyve-tretti år vært klare tendenser begge steder til en nedbygging av det offentliges ansvar på en del områder, og interessant nok har det også bidratt til at enkelte teologer, prester og biskoper har etterlyst en mer aktiv stat på det sosiale feltet. Man har etterlyst en stat som bryr seg mer om de marginaliserte og fattige, om de som faller utenfor. Frivillige organisasjoner og kirken har fylt mange slike rom. Det er ikke noe nytt. Gjennom hele velferdsstatens fremvekst etter krigen har det vært områder hvor statlige interesser har vært svakere. For eksempel har det hele tiden innenfor rusfeltet vært et stort antall frivillige organisasjoner, inkludert kristelige. Sykehjem, sykehus, hjemmesykepleie osv. har derimot vært et i økende grad offentlig ansvar og blitt underlagt strengere reguleringer. Det skal også sies at i Norge ble velferdsstatens utbygging muliggjort gjennom infrastrukturen som diakonale organisasjoner, sykehus og liknende representerte. Det tydeligste eksemplet på det er menighetssøstrenes innlemming i hjemmesykepleien.

Når Spencer peker på statens store mangel på penger som en aktuell utfordring og som er blitt akutt under koronapandemien, så har Norge hatt den fordel at oljefondet har gjort det mulig å hjelpe oss gjennom ulike kriser de siste årene, som finanskrisen i 2008 og covid-19 nå. Det har også gitt oss erfaring av hvor avhengig marked og sivilsamfunn er av en sterk stat. Den norske velfersstatsmodellen har også basert seg på at frivillig og privat hjelp på sosialfeltet skal understøttes med offentlige midler. Staten har i den perioden vi har vært igjennom og fortsatt befinner oss midt i, kunnet gi understøttelse til bedrifter som ellers ville gått 
konkurs, og bidratt med ekstra støtte til frivillige organisasjoner som kan gi hjelp til mennesker som mister nettverk. I Dagens intervju med Spencer trekker han også opp det samme kritiske poeng som Eivind Berggrav hadde, nemlig at staten ikke kan løse de relasjonelle behov og utfordringer som mennesker har. Kirken og frivillige organisasjoner representerer noe som er helt umistelig i et samfunn. De er arenaer hvor man kan få engasjere seg, hvor man kan handle og samvirke med andre. Det altruistiske behovet som fins, svares ikke ut gjennom offentlige tjenester.

Jeg tror at sivilsamfunnet står sterkt og vil stå enda sterkere i årene som kommer. Der tenker jeg Berggrav hadde rett, at det trengs et nedenfra-perspektiv på det menneskelige samfunnet. Jeg opplever også at kirken i enda større grad enn hva ofte skjer, kunne snakke høyt om hvilken infrastruktur den representerer når det gjelder å skape møteplasser som favner det åndelige, eksistensielle og sosiale. Her skjer det tidvis en underkommunisering av kompetanse, kunnskap og virke. For å ta et eksempel: Når det er bispeinnsettelser er ordfører, fylkesordfører etc. til stede, og det holdes taler fra det offentlige Norge til den nye biskopen. Det er taler som uttrykker forventning om samarbeid og anerkjennelse av kirkens betydning for lokalsamfunnet. Jeg synes kirken gjennom sine taler i denne sammenheng med fordel kunne besvare dette mer offensivt. I stedet for å rette blikket innover og la all tale være personlig til den nyutnevnte biskop, kunne man anerkjenne tilstedeværelsen av det offentlige Norge og plassere kirken inn i den rettmessig viktige posisjon den har som forvalter av en arv og et arbeid som hver eneste dag når titusener av mennesker. Det er få som kan konkurrere med kirken. Gjennom evangeliets spore til forkynnelse og sosial handling, og gjennom de mange dyktige prester, diakoner og andre kirkelige medarbeidere og frivillige, sitter kirken på en skatt av umistelig betydning for samfunnet. Det er et arbeid som også holder en kvalitet som det er grunn til å snakke frem. Som åndelig, eksistensiell og sosial meningsbærer har kirken en plass i sivilsamfunnet som skiller den fra en rekke andre aktører. Biskop Eivind Berggrav omtalte kirken som statens samvittighet, og kritiserte velferdsstaten for å redusere det eksterne korrektiv som kirken representerte. Det er en kritisk kommentar som kan ha gyldighet også i dag. ${ }^{5}$

\footnotetext{
Noter

1 [Red.] Denne artikkelen er tidligere publisert som kronikk i Dagen, 1. februar 2021, s. 18-19. Den republiseres her med tillatelse både fra avisen og forfatteren. Kronikken var skrevet på bakgrunn av Dagens intervju med Nick Spencer i samme avis.

2 [Red.] Ingressen er formulert av redaksjonen.

3 [Red.] Nick Spencer, Multi-dimensional personhood and the welfare state (Doctoral thesis, 2020, University of Cambridge), https://doi.org/10.17863/CAM.60916.

4 [Red.] «Ser rom for kirken der staten må gi tapt», Dagen, 1. februar 2021, s. 6-7.

5 [Red.] For videre utforsking av velferdsstaten som tema, henvises til flere aktuelle publikasjoner fra artikkelforfatteren, se https://www.ft.uio.no/personer/vit/audt/.
} 